\title{
Review Article \\ Fulminant Type 1 Diabetes as a Model of Nature to Explore the Role of C-Peptide
}

\author{
Yuko Murase-Mishiba, A. Imagawa, and Toshiaki Hanafusa \\ First Department of Internal Medicine, Osaka Medical College, 2-7 Daigaku-Machi, Takatsuki 569-8686, Japan \\ Correspondence should be addressed to Toshiaki Hanafusa, hanafusa@poh.osaka-med.ac.jp
}

Received 27 November 2007; Accepted 26 February 2008

Recommended by Thomas Forst

Patients with fulminant type 1 diabetes almost completely lack C-peptide even soon after the onset of the disease, and the deficiency continues for the rest of their life. Thus, fulminant type 1 diabetes could serve as a good model of nature to explore the physiological role of C-peptide. For example, patients with fulminant type 1 diabetes have diabetic chronic complications more frequently than those with classical autoimmune type 1 diabetes 5 years after the onset of diabetes, and the higher prevalence could be partly attributable to the complete lack of C-peptide in fulminant type 1 diabetes.

Copyright (C) 2008 Yuko Murase-Mishiba et al. This is an open access article distributed under the Creative Commons Attribution License, which permits unrestricted use, distribution, and reproduction in any medium, provided the original work is properly cited.

Type 1 diabetes mellitus is characterized by an insulin deficiency resulting from the destruction of pancreatic $\beta$-cells. Recently, a novel subtype of type 1 diabetes has been recorded and referred to as fulminant type 1 diabetes, which accounts for approximately $20 \%$ of Japanese ketosis-onset type 1 diabetes $[1,2]$. Fulminant type 1 diabetes has the following clinical characteristics: duration of hyperglycemic symptoms is 4 days on average; a high prevalence of preceding common cold-like and gastrointestinal symptoms; a near-normal level of glycated hemoglobin in spite of very high plasma glucose levels associated with ketoacidosis, sometimes related to pregnancy; and increased serum pancreatic enzyme levels, absent C-peptide levels (fasting serum C-peptide $<0.10 \mathrm{nmol} / \mathrm{L}$ or stimulated serum C-peptide $<$ $0.17 \mathrm{nmol} / \mathrm{L}$ soon after the disease onset), but virtually no detectable autoantibodies against constituents of pancreatic $\beta$-cells. The process of $\beta$-cell destruction is extremely rapid. Of note, in contrast to autoimmune type 1A diabetes, the deficiency of insulin secretory capacity has already become almost complete even at onset of diabetes, and the capacity rarely recovers after the onset. The patients are treated with recombinant human insulin, but C-peptide is not replaced. Thus, fulminant type 1 diabetes could serve as a good model of nature to explore the physiological role of C-peptide.

We conducted a nationwide survey in Japan to assess the development of microvascular complications in fulminant type 1 diabetes of 5 years' duration in comparison with acute-onset autoimmune type 1A diabetes [3, 4]. Five-year cumulative incidence of microangiopathy was $24.4 \%$ in fulminant type 1 diabetes and $2.6 \%$ in type $1 \mathrm{~A}$ diabetes. The cumulative incidence of each microangiopathy was significantly higher in fulminant type 1 diabetes than in type 1A diabetes; retinopathy was $9.8 \%$ versus $0 \%(P=.014)$, nephropathy $12.2 \%$ versus $2.6 \%(P=.015)$, and neuropathy $12.2 \%$ versus $1.3 \%(P=.010)$, respectively. Also, logistic regression analysis showed that decreased C-peptide secretion was a risk for retinopathy $(\beta=0.29 ; P=.04, \beta=$ $-0.27 ; P<.05$, resp. $)$ and neuropathy $(\beta=0.39, P=.01 ; \beta=$ $-0.25, P<.05$, resp.). Mean $\mathrm{HbA}_{1 c}$ levels were similar in fulminant and type $1 \mathrm{~A}$ diabetes group during the follow-up periods. However, mean $M$-value, mean insulin dosages, and the frequency of severe hypoglycemic episodes were significantly higher, and mean postprandial C-peptide level was significantly lower in fulminant type 1 diabetes than in type 1 A diabetes $(0.08 \pm 0.04$ versus $0.24 \pm 0.15 \mathrm{nmol} / \mathrm{L}, P=$ $.0007)$. These results suggest that depleted and irreversible insulin production is associated with unstable blood glucose control, as indicated by increased $M$-value, and thereby high incidence of diabetic microvascular complications in fulminant type 1 diabetic patients. Here, the following interpretation is possible: lack of C-peptide itself (Figure 1), in addition to instability of glucose levels, might play a role in the development of microangiopathy in fulminant type 1 diabetic patients. Indeed, the mean postprandial C-peptide 


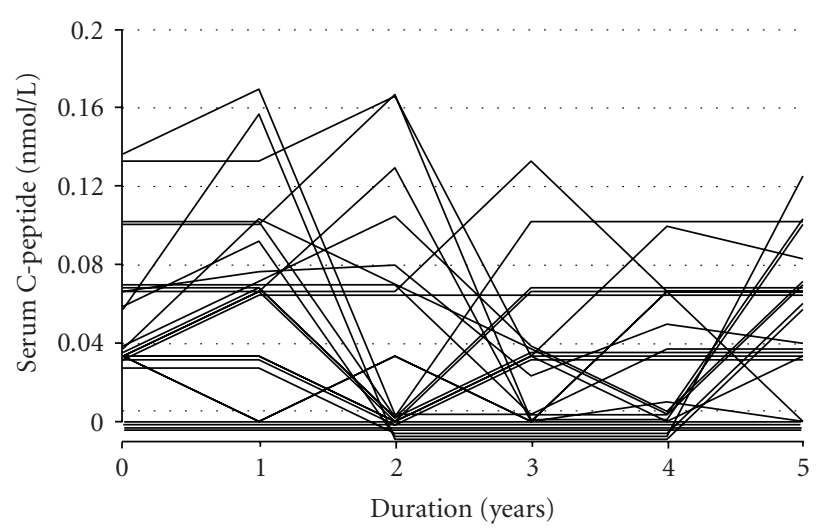

Figure 1: Serum C-peptide levels for 5 years from fulminant diabetes onset. Adapted from [4].

levels were almost undetectable even at the onset of diabetes $(0.06 \pm 0.03 \mathrm{nmol} / \mathrm{L})$ and throughout the 5-year study in fulminant diabetic patients, while they were detectable at and decreased gradually after the onset in classical type $1 \mathrm{~A}$ diabetes $[5,6]$.

C-peptide has been considered to be a good marker of insulin secretion and has no biological activity of its own. However, over the last decade, several reports have suggested that C-peptide exerts a number of physiological effects, which are probably mediated by stimulation of $\mathrm{Na}^{+}, \mathrm{K}^{+}$-ATPase, and endothelial nitric oxide synthetase activities in several tissues [7]. At the early stage of type 1 diabetes, C-peptide replacement was shown to result in diminished urinary albumin excretion rate and ameliorates nerve dysfunction [8]. In the light of these data, fulminant type 1 diabetes could provide an ideal setting to explore whether C-peptide administration benefits patients with diabetes in reducing microangiopathy.

\section{ACKNOWLEDGMENTS}

This study was supported in part by a grant-in-aid from the Japanese Society for the Promotion of Science (KAKENHI) (19790641, 19591087, 19591069), a grant from The Naito Foundation (2007), and a grant from Takeda Science Foundation (2007).

\section{REFERENCES}

[1] A. Imagawa, T. Hanafusa, J. Miyagawa, and Y. Matsuzawa, "A novel subtype of type 1 diabetes mellitus characterized by a rapid onset and an absence of diabetes-related antibodies," The New England Journal of Medicine, vol. 342, no. 5, pp. 301-307, 2000.

[2] A. Imagawa, T. Hanafusa, Y. Uchigata, et al., "Fulminant type 1 diabetes. A nationwide survey in Japan," Diabetes Care, vol. 26, no. 8, pp. 2345-2352, 2003.

[3] Y. Murase, A. Imagawa, T. Hanafusa, et al., "Fulminant type 1 diabetes as a high risk group for diabetic microangiopathy-a nationwide 5-year-study in Japan,” Diabetologia, vol. 50, no. 3, pp. 531-537, 2007.

[4] T. Hanafusa, A. Imagawa, H. Iwahashi, et al., "Report of the committee of the Japan diabetes society on research on fulmi- nant type 1 diabetes mellitus: analysis of HLA serotype and diabetic microangiopathy," Journal of the Japan Diabetic Society, vol. 50, pp. 825-833, 2007, Japanese.

[5] The Diabetes Control Complications Trial Research Group, "The effect of intensive treatment of diabetes on the development and progression of long-term complications in insulindependent diabetes mellitus," The New England Journal of Medicine, vol. 329, no. 14, pp. 977-986, 1993.

[6] The Diabetes Control Complications Trial Research Group, "Effect of intensive therapy on residual $\beta$-cell function in patients with type 1 diabetes in the diabetes control and complications trial. A randomized, controlled trial," Annals of Internal Medicine, vol. 128, no. 7, pp. 517-523, 1998.

[7] Y. Ido, A. Vindigni, K. Chang, et al., "Prevention of vascular and neural dysfunction in diabetic rats by C-peptide," Science, vol. 277, no. 5325, pp. 563-566, 1997.

[8] B. L. Johansson, K. Borg, E. Fernqvist-Forbes, A. Kernell, T. Odergren, and J. Wahren, "Beneficial effects of C-peptide on incipient nephropathy and neuropathy in patients with type 1 diabetes mellitus," Diabetic Medicine, vol. 17, no. 3, pp. 181$189,2000$. 


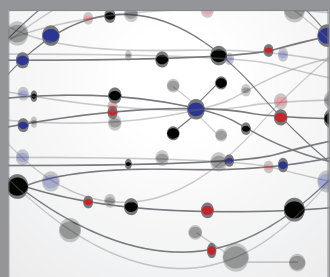

The Scientific World Journal
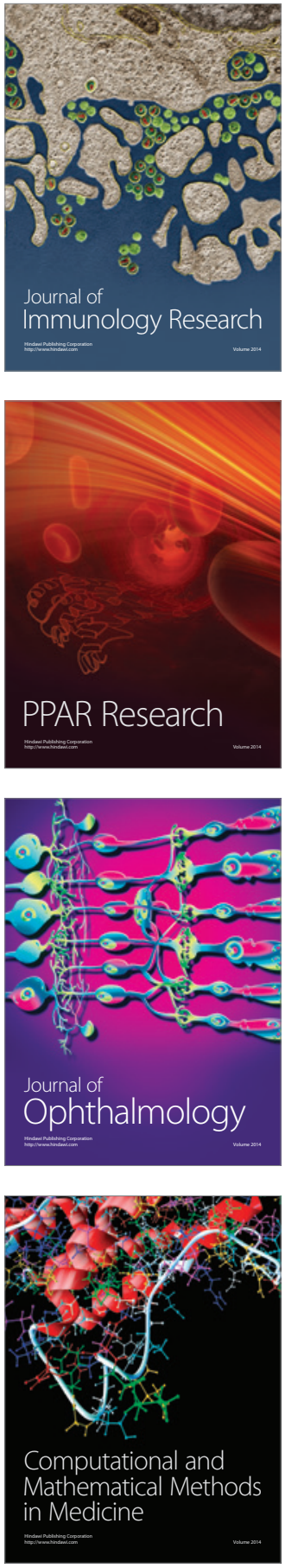

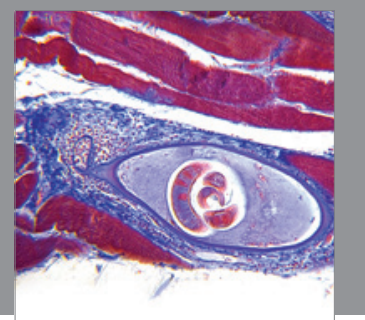

Gastroenterology

Research and Practice
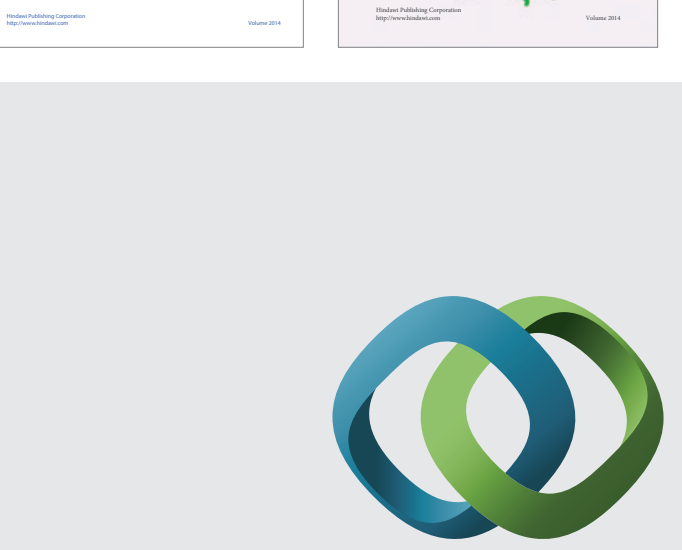

\section{Hindawi}

Submit your manuscripts at

http://www.hindawi.com
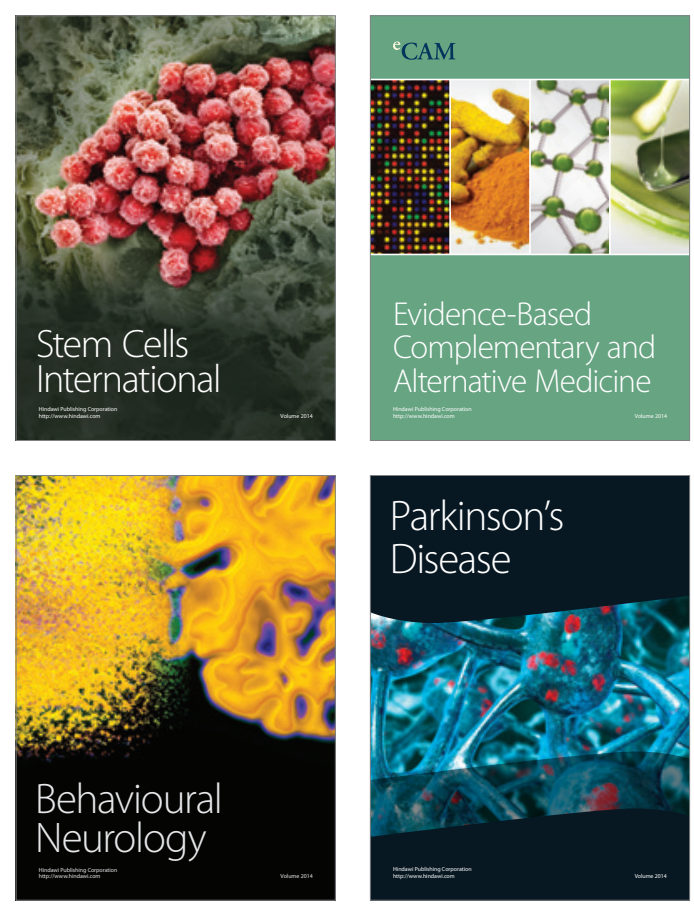

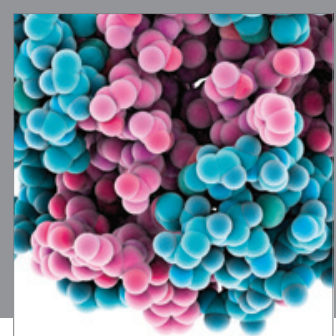

Journal of
Diabetes Research

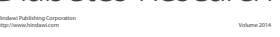

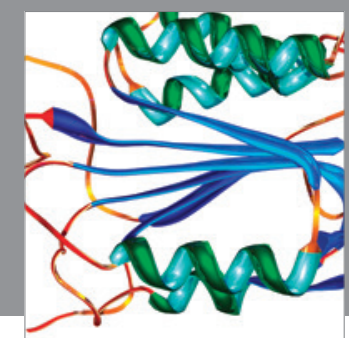

Disease Markers
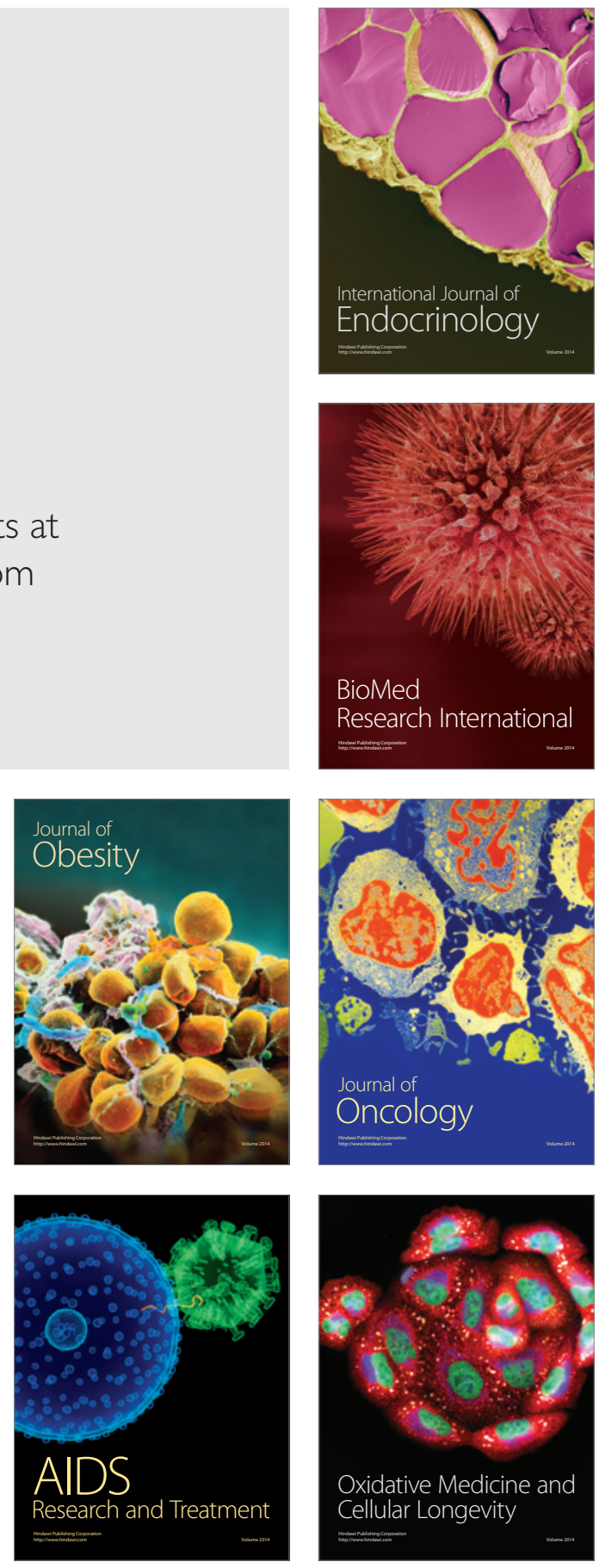